\title{
Studies on the Effect of Planting Density and Nutrient Management on Yield, Fruit Quality and Post Harvest Characters in Banana cv. Ney Poovan under Coconut
}

\author{
G. Panjavarnam*, S. Parthiban, A. Subbiah, P. Jeyakumar and N.O. Gopal \\ Department of Fruit Crops, HC \& RI, TNAU, Coimbatore, Tamil Nadu State, India \\ *Corresponding author
}

\section{Keywords}

Planting density,

Nutrient

management,

Yield, Fruit quality,

Post harvest

Article Info

Accepted:

07 November 2018

Available Online:

10 December 2018

\section{A B S T R A C T}

A field experiment was conducted during the year 2017 - 2018 to evaluate the effect of planting density and nutrient management on yield, fruit quality and post harvest characters in banana cv. Ney Poovan under coconut with nine treatments replicated thrice by using factorial randomized block design. Coconut being widely spaced owing to its morphological features provides ample opportunities for cropping in the interspaces. Active root zone of coconut is confined to 25 per cent of the available land area and the remaining area could be profitably exploited for raising subsidiary crops. The present results revealed that among the different treatments, $\mathrm{F}_{6} \mathrm{P}_{1}(100$ per cent of the RDF + Azospirllum @100 g + Phosphobacteria@100 g + AM fungi@100 g plant ${ }^{-1}$ in single row planting) recorded best values in term of yield, quality and post harvest parameters. Hence, the application of 100 per cent of the RDF + Azospirllum @ 100 g + Phosphobacteria@100 g + AM fungi@100 g plant ${ }^{-1}$ in single row planting system in banana cv. Ney Poovan under coconut is best when compared to other treatment and control.

\section{Introduction}

Banana (Musa spp.) is the second largest fruit crop in the world. In India, it is one of the most important commercial fruits. Banana is originated from South East Asia, a region considered as the primary centre of diversification of the crop and where earlier domestication has occurred (Simmonds, 1962). Banana and plantain are mostly grown not only for their nutritional value but also for their economic importance. Banana is a heavy feeder of nutrients and nearly 25 to 30 per cent of cost of inputs goes for fertilizers and manures. It is estimated that a crop of $50 \mathrm{t} \mathrm{ha}^{-1}$ of banana removes $320 \mathrm{~kg}$ of $\mathrm{N}, 32 \mathrm{~kg}$ of $\mathrm{P}_{2} \mathrm{O}_{5}$ and $325 \mathrm{~kg}$ of $\mathrm{K}_{2} \mathrm{O}$ every year (Lahav and Turner, 1983). Hence, it is of importance to maintain high degree of soil fertility by timely and judicious application of NPK to achieve yield and quality of banana. However, increased use of inorganic fertilizers for production of banana has resulted in several undesirable consequences, in the fragile soil eco system leading to gradual decline in productivity (Prabhuram, 1992). Therefore, 
the present investigation to study the impact of planting density and nutrient management on yield, fruit quality and post harvest characters in banana cv. Ney Poovan under coconut.

\section{Materials and Methods}

The present investigation carried out at Department of fruit crops, Horticultural College and Research Institute, Tamil Nadu Agricultural University, Coimbatore during the period 2017 - 2018 with banana cv. Ney Poovan under coconut. The experiment was laid out in a Factorial Randomized Block Design with nine treatments and three replications. Each treatment had a net area of $200 \mathrm{M}^{2}$ having 45 plants. Guard rows were provided on all sides of the plots. Observations were taken up from centrally located ten plants. The recommended spacing of $1.8 \mathrm{~m} \mathrm{x} 1.8 \mathrm{~m}$ was adopted for planting. Suckers of banana $c v$. Ney Poovan obtained from disease free field were planted in all the treatments. Recommended cultural practices were carried out regularly. Suckers of uniform size weighing around $1.5 \mathrm{~kg} \pm 0.5 \mathrm{~kg}$ of banana cv. Ney Poovan were selected for planting. The present experiment of various treatments as follows $\mathrm{F}_{1} \mathrm{P}_{1}(75$ per cent $\mathrm{RDF}$ in single row planting), $\mathrm{F}_{2} \mathrm{P}_{1}(100$ per cent RDF in single row planting), $F_{3} P_{1}$ (125 per cent $\mathrm{RDF}$ in single row planting), $\mathrm{F}_{4} \mathrm{P}_{1}$ (150 per cent $\mathrm{RDF}$ in single row planting), $\mathrm{F}_{5} \mathrm{P}_{1}$ (75 per cent of the RDF + Azospirllum @ $100 \mathrm{~g}+$ Phosphobacteria@100 g + AM fungi @ 100 g plant ${ }^{-1}$ in single row planting), $\mathrm{F}_{6} \mathrm{P}_{1}$ (100 per cent of the RDF + Azospirllum @ $100 \mathrm{~g}+$ Phosphobacteria@100 g + AM fungi @ 100 g plant ${ }^{-1}$ in single row planting), $\mathrm{F}_{7} \mathrm{P}_{1}$ (125 per cent of the RDF + Azospirllum @100 g + Phosphobacteria@100 g + AM fungi@100 g plant ${ }^{-1}$ in single row planting), $\mathrm{F}_{8} \mathrm{P}_{1}$ (150 per cent of the RDF + Azospirllum @ $100 \mathrm{~g}+$ Phosphobacteria@100 g + AM fungi @100 $\mathrm{g}$ plant $^{-1}$ in single row planting), $\mathrm{F}_{9} \quad \mathrm{P}_{1}$ (control) and $\mathrm{F}_{1} \mathrm{P}_{2}$ (75 per cent $\mathrm{RDF}$ in double row planting), $\mathrm{F}_{2} \mathrm{P}_{2}(100$ per cent $\mathrm{RDF}$ in double row planting), $\mathrm{F}_{3} \mathrm{P}_{2}$ (125 per cent $\mathrm{RDF}$ in single row planting), $\mathrm{F}_{4} \mathrm{P}_{2}$ (150 per cent RDF in double row planting), $\mathrm{F}_{5} \mathrm{P}_{2}$ (75 per cent of the RDF + Azospirllum @ $100 \mathrm{~g}+$ Phosphobacteria@100 g + AM fungi @ 100 $\mathrm{g}_{\text {plant }}{ }^{-1}$ in double row planting), $\mathrm{F}_{6} \mathrm{P}_{2}(100$ per cent of the RDF + Azospirllum @ $100 \mathrm{~g}+$ Phosphobacteria@100 g + AM fungi@100 g plant ${ }^{-1}$ in double row planting), $\mathrm{F}_{7} \mathrm{P}_{2}$ (125 per cent of the RDF + Azospirllum @ $100 \mathrm{~g}+$ Phosphobacteria@100 g + AM fungi @ 100 g plant ${ }^{-1}$ in double row planting), $\mathrm{F}_{8} \mathrm{P}_{2}$ (150 per cent of the RDF + Azospirllum @ $100 \mathrm{~g}+$ Phosphobacteria@100 g + AM fungi @ 100 $\mathrm{g}$ plant $^{-1}$ in double row planting), $\mathrm{F}_{9} \quad \mathrm{P}_{2}$ (control). The recommended dose of fertilizer (RDF) for banana cv. Ney Poovan: $110 \mathrm{~g}: 35$

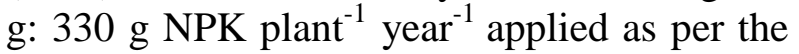
treatment schedule. Ten uniform plants were selected randomly in each treatment for recording the following observations on vegetative characters at $3^{\text {rd }}, 5^{\text {th }}, 7^{\text {th }}$ month and shooting stage after planting. The yield and quality attributes were taken after harvesting of bunches.

\section{Results and Discussion}

\section{Yield and yield attributing characters}

Among the different nutrient treatments, the plants treated with $\mathrm{F}_{6}$ (100 per cent of the $\mathrm{RDF}+$ Azospirllum @ $100 \mathrm{~g}$ + Phosphobacteria@100 g + AM fungi @ 100 $\mathrm{g}$ plant $^{-1}$ ) registered highest bunch weight more number of hands per bunch, more number of fingers per bunch, highest finger weight viz., (9.47 kg), (7.77 hands), (94.45 fingers and $(69.65 \mathrm{~g})$ respectively compared to other treatments. Among the planting density, the highest bunch weight $(8.81 \mathrm{~kg})$, the more number of fingers per bunch (86.89 fingers), highest finger weight $(68.76 \mathrm{~g})$ registered in $\mathrm{P}_{1}$ (single row planting) compared to other level but no significant difference in case of number 
hands per bunch. The interaction effect between $\mathrm{F}$ and $\mathrm{P}$ were significantly differ in respect to yield and quality parameters, highest bunch weight $(9.55 \mathrm{~kg})$, more number of hands per bunch (7.75 hands), the more number of fingers per bunch (93.80 fingers), the highest finger weight $(69.18 \mathrm{~g})$ recorded in the treatment $\mathrm{F}_{6} \quad \mathrm{P}_{1}$ compared to other treatment combinations (Table 1). The results revealed that positive influence between total number of leaves producd and the yield of the crop which is maximum in the treatment $\mathrm{F}_{6} \mathrm{P}_{1}$. It is in line with the results of vidhya, 2004. Bunch weight is a primary function of number of fingers and finger weight (Krishna and shanmugavelu, 1983). In banana, the floral differentiation requires minimum functional leaf area and high photosynthetic assimilation favourd by improved nutrient status, better differentiation, leading to more finger and better flow of assimilates to developing fingers, could be attributed for better bunch weight. The results are line with Murugan, 2003.

\section{Quality and post harvest parameters}

Among the different nutrient treatments, the plants treated with $\mathrm{F}_{6}$ (100 per cent of the
$\mathrm{RDF}+$ Azospirllum @ $100 \mathrm{~g}$ + Phosphobacteria@100 g + AM fungi@100 $\mathrm{g} \mathrm{plant}^{-1}$ ) registered highest total soluble solids (23.45\%), highest total sugar content (18.02 $\%)$, highest reducing sugar content $(12.76 \%)$, highest non-reducing sugar content $(5.60 \%)$ respectively compared to other treatments. Among the planting density, the total sugar content $(17.22 \%)$ registered in $\mathrm{P}_{1}$ (single row planting) compared to other level but no significant difference in case of TSS, reducing and non reducing sugar content. The interaction effect between $F$ and $P$ were significantly differ in respect to yield and quality parameters, the highest total soluble solids recorded in the treatment $\mathrm{F}_{6} \mathrm{P}_{2}$ (23.48\%), the highest total sugar content recorded in the treatment $\mathrm{F}_{6} \mathrm{P}_{1}(18.14 \%)$, the highest reducing sugar content recorded in the treatment $\mathrm{F}_{7} \mathrm{P}_{2}(12.77 \%)$ the highest nonreducing sugar content recorded in the treatment $\mathrm{F}_{6} \mathrm{P}_{2}(5.60 \%)$ compared to other treatment combinations (Table 2). In banana, the most important traits that decide fruit quality is total soluble solids, total sugars, acidity and ascorbic acid. The results are in line with the findings of vanilarasu et al., (2018) in banana.

Table.1 Effect of planting density and nutrient management on yield and yield attributes in banana cv. Ney Poovan

\begin{tabular}{|c|c|c|c|c|c|c|c|c|c|c|c|c|}
\hline Treatments & \multicolumn{3}{|c|}{ Bunch weight (kg plant ${ }^{-1}$ ) } & \multicolumn{3}{|c|}{ Number of hands (numbers) } & \multicolumn{3}{|c|}{ Number of fingers (numbers) } & \multicolumn{3}{|c|}{ Finger weight (g) } \\
\hline & $\mathbf{P}_{1}$ & $\mathbf{P}_{2}$ & F Mean & $\mathbf{P}_{1}$ & $\mathbf{P}_{2}$ & F Mean & $\mathbf{P}_{1}$ & $\mathbf{P}_{2}$ & F Mean & $\mathbf{P}_{1}$ & $\mathbf{P}_{2}$ & F Mean \\
\hline$F_{1}$ & 9.31 & 9.91 & 9.25 & 7.38 & 7.35 & 7.36 & 88.82 & 88.63 & 88.72 & 55.10 & 53.15 & 54.12 \\
\hline $\mathbf{F}_{2}$ & 8.85 & 8.80 & 8.82 & 7.35 & 7.32 & 7.33 & 87.05 & 86.92 & 86.98 & 63.00 & 62.10 & 62.55 \\
\hline$F_{3}$ & 9.35 & 9.30 & 9.32 & 7.34 & 7.32 & 7.33 & 87.23 & 87.13 & 87.18 & 66.49 & 62.11 & 64.30 \\
\hline $\mathbf{F}_{4}$ & 8.59 & 8.49 & 8.54 & 7.42 & 7.36 & 7.39 & 88.76 & 88.51 & 88.63 & 60.52 & 58.65 & 59.58 \\
\hline$F_{5}$ & 8.42 & 8.32 & 8.38 & 7.42 & 7.37 & 7.39 & 87.54 & 87.32 & 87.43 & 64.31 & 57.26 & 60.78 \\
\hline$F_{6}$ & 9.55 & 9.40 & 9.47 & 7.75 & 7.79 & 7.77 & 93.80 & 94.45 & 94.12 & 69.18 & 70.12 & 69.65 \\
\hline$F_{7}$ & 8.67 & 8.67 & 8.67 & 7.32 & 7.30 & 7.31 & 85.15 & 84.92 & 85.03 & 65.65 & 61.34 & 63.49 \\
\hline$\overline{F_{8}}$ & 8.51 & 8.51 & 8.51 & 7.40 & 7.39 & 7.39 & 85.47 & 85.06 & 85.26 & 64.32 & 58.40 & 61.36 \\
\hline $\mathrm{F}_{9}$ & 8.10 & 8.07 & 8.08 & 6.49 & 6.50 & 6.49 & 78.24 & 77.97 & 78.10 & 48.54 & 50.00 & 49.21 \\
\hline P Mean & 8.81 & 8.75 & 8.78 & 7.31 & 7.30 & 7.30 & 86.89 & 86.76 & 86.82 & 68.76 & 59.23 & 63.99 \\
\hline & & SEd & $\begin{array}{r}\text { CD } \\
(P=0.05)\end{array}$ & & SEd & $\mathrm{CD}(\mathrm{P}=0.05)$ & & SEd & $\begin{array}{r}\text { CD } \\
(P=0.05)\end{array}$ & & SEd & $\begin{array}{r}\text { CD } \\
(P=0.05)\end{array}$ \\
\hline $\mathbf{P}$ & & 0.03 & 0.06 & & 0.041 & 0.078 & & 0.516 & 0.861 & & 0.46 & 0.78 \\
\hline $\mathbf{F}$ & & 0.06 & 0.10 & & 0.081 & 0.162 & & 0.891 & 1.98 & & 0.82 & 1.68 \\
\hline $\mathbf{P} \times \mathbf{F}$ & & 0.10 & 0.14 & & 0.118 & 0.221 & & 1.31 & 2.76 & & 1.16 & 2.36 \\
\hline
\end{tabular}


Table.2 Effect of planting density and nutrient management on quality attributes in banana cv. Ney Poovan

\begin{tabular}{|c|c|c|c|c|c|c|c|c|c|c|c|c|}
\hline \multirow[t]{2}{*}{ Treatments } & \multicolumn{3}{|c|}{ TSS $\left({ }^{0}\right.$ Brix $)$} & \multicolumn{3}{|c|}{ Total sugars (\%) } & \multicolumn{3}{|c|}{ Reducing sugars (\%) } & \multicolumn{3}{|c|}{$\begin{array}{c}\text { Non - reducing Sugars } \\
(\%)\end{array}$} \\
\hline & $\mathbf{P}_{1}$ & $\mathbf{P}_{2}$ & F Mean & $\mathbf{P}_{1}$ & $\mathbf{P}_{2}$ & F Mean & $\mathbf{P}_{1}$ & $\mathbf{P}_{2}$ & F Mean & $\mathbf{P}_{1}$ & $\mathbf{P}_{2}$ & F Mean \\
\hline $\mathbf{F}_{1}$ & 21.14 & 21.16 & 21.14 & 17.48 & 16.39 & 16.93 & 12.09 & 12.10 & 12.08 & 5.39 & 5.38 & 5.39 \\
\hline$F_{2}$ & 20.80 & 20.82 & 20.81 & 16.77 & 16.17 & 16.47 & 11.32 & 11.34 & 11.33 & 5.45 & 5.48 & 5.47 \\
\hline$F_{3}$ & 20.29 & 20.30 & 20.29 & 17.87 & 16.58 & 17.22 & 12.34 & 12.34 & 12.34 & 5.54 & 5.56 & 5.54 \\
\hline$F_{4}$ & 22.13 & 22.14 & 22.13 & 17.45 & 16.72 & 17.08 & 12.06 & 12.08 & 12.07 & 5.40 & 5.36 & 5.39 \\
\hline$F_{5}$ & 21.98 & 21.98 & 21.98 & 17.50 & 16.50 & 17.00 & 12.23 & 12.25 & 12.24 & 5.27 & 5.26 & 5.27 \\
\hline$F_{6}$ & 23.46 & 23.48 & 23.45 & 18.14 & 17.89 & 18.02 & 12.55 & 12.56 & 12.54 & 5.60 & 5.60 & 5.60 \\
\hline$F_{7}$ & 23.04 & 23.06 & 23.05 & 17.98 & 16.61 & 17.29 & 12.76 & 12.77 & 12.76 & 5.22 & 5.24 & 5.22 \\
\hline $\mathbf{F}_{8}$ & 21.99 & 21.94 & 21.95 & 17.84 & 16.69 & 17.27 & 12.58 & 12.58 & 12.58 & 5.26 & 5.28 & 5.27 \\
\hline$F_{9}$ & 18.70 & 18.62 & 18.67 & 14.00 & 13.07 & 13.54 & 9.42 & 9.37 & 9.39 & 4.50 & 4.42 & 4.46 \\
\hline P Mean & 21.50 & 21.49 & 21.50 & 17.22 & 16.29 & 16.76 & 11.93 & 11.91 & 11.92 & 5.29 & 5.28 & 5.28 \\
\hline & & SEd & $\begin{array}{r}\text { CD } \\
(P=0.05)\end{array}$ & & SEd & $\begin{array}{r}C D \\
(P=0.05)\end{array}$ & & SEd & $\begin{array}{r}\text { CD } \\
(P=0.05)\end{array}$ & & SEd & $\begin{array}{r}C D \\
(P=0.05)\end{array}$ \\
\hline $\mathbf{P}$ & & 0.116 & 0.237 & & 0.097 & 0.197 & & 0.063 & 0.128 & & 0.010 & 0.022 \\
\hline $\mathbf{F}$ & & 0.248 & 0.504 & & 0.206 & 0.419 & & 0.133 & 0.271 & & 0.023 & 0.047 \\
\hline$P \times F$ & & 0.350 & 0.713 & & 0.291 & 0.592 & & 0.189 & 0.384 & & 0.032 & 0.066 \\
\hline
\end{tabular}

Table.3 Effect of planting density and nutrient management on quality and post harvest parameters in banana cv. Ney Poovan

\begin{tabular}{|c|c|c|c|c|c|c|c|c|c|c|c|c|}
\hline Treatments & \multicolumn{3}{|c|}{ Ascorbic acid (mg $\left.100 \mathrm{~g}^{-1}\right)$} & \multicolumn{3}{|c|}{ Acidicity (\%) } & \multicolumn{3}{|c|}{ Shelf life of fruit (days) } & \multicolumn{3}{|c|}{ Sugar-acid ratio } \\
\hline & $\mathbf{P}_{1}$ & $\mathbf{P}_{2}$ & F Mean & $\mathbf{P}_{1}$ & $\mathbf{P}_{2}$ & F Mean & $\mathbf{P}_{1}$ & $\mathbf{P}_{2}$ & F Mean & $\mathbf{P}_{1}$ & $\mathbf{P}_{2}$ & F Mean \\
\hline $\mathbf{F}_{1}$ & 7.38 & 7.37 & 7.37 & 0.38 & 0.37 & 0.37 & 10.32 & 10.33 & 10.32 & 45.41 & 44.82 & 45.11 \\
\hline$\overline{F_{2}}$ & 7.48 & 7.46 & 7.46 & 0.34 & 0.34 & 0.33 & 10.45 & 10.46 & 10.45 & 49.41 & 48.18 & 48.79 \\
\hline $\mathbf{F}_{3}$ & 7.57 & 7.56 & 7.56 & 0.41 & 0.38 & 0.39 & 10.44 & 10.44 & 10.44 & 43.24 & 43.67 & 43.45 \\
\hline$\overline{F_{4}}$ & 7.70 & 7.69 & 7.69 & 0.38 & 0.36 & 0.37 & 10.33 & 10.34 & 10.33 & 45.98 & 46.94 & 46.46 \\
\hline $\mathbf{F}_{5}$ & 7.69 & 7.69 & 7.68 & 0.32 & 0.33 & 0.33 & 10.40 & 10.41 & 10.40 & 54.29 & 50.71 & 52.50 \\
\hline$\overline{F_{6}}$ & 7.93 & 7.92 & 7.91 & 0.26 & 0.27 & 0.26 & 10.81 & 10.80 & 10.80 & 70.05 & 67.17 & 68.61 \\
\hline$\overline{F_{7}}$ & 7.49 & 7.48 & 7.48 & 0.29 & 0.34 & 0.32 & 10.73 & 10.72 & 10.72 & 63.64 & 48.89 & 56.26 \\
\hline$\overline{F_{8}}$ & 7.40 & 7.39 & 7.39 & 0.37 & 0.35 & 0.36 & 10.34 & 10.34 & 10.34 & 48.52 & 47.56 & 48.04 \\
\hline$\overline{F_{9}}$ & 7.20 & 7.23 & 7.21 & 0.33 & 0.38 & 0.35 & 9.63 & 8.83 & 9.23 & 42.42 & 34.45 & 38.48 \\
\hline P Mean & 7.53 & 7.52 & 7.53 & 0.34 & 0.34 & 0.34 & 10.38 & 10.29 & 10.33 & 51.45 & 48.04 & 49.74 \\
\hline & & SEd & $\begin{array}{r}\text { CD } \\
(\mathbf{P}=\mathbf{0 . 0 5})\end{array}$ & & SEd & $\begin{array}{r}\text { CD } \\
(P=0.05)\end{array}$ & & SEd & $\begin{array}{r}C D \\
(P=0.05)\end{array}$ & & SEd & $\begin{array}{r}\mathrm{CD} \\
(\mathbf{P}=\mathbf{0 . 0 5})\end{array}$ \\
\hline $\mathbf{P}$ & & 0.012 & 0.026 & & 0.008 & 0.016 & & 0.022 & 0.046 & & 1.37 & 2.79 \\
\hline $\bar{F}$ & & 0.027 & 0.055 & & 0.017 & 0.035 & & 0.048 & 0.098 & & 2.91 & 5.92 \\
\hline $\mathbf{P} \times \mathbf{F}$ & & 0.038 & 0.078 & & 0.024 & 0.050 & & 0.068 & 0.139 & & 4.12 & 8.38 \\
\hline
\end{tabular}


The highest total sugar content might be due to the role of potassium which is involved in carbohydrate synthesis, breakdown and translocation and synthesis of protein and neutralization of physiologically important organic acids (Tisdale and Nelson, 1966).

Among the different nutrient treatments, the plants treated with $\mathrm{F}_{6}$ (100 per cent of the $\mathrm{RDF}+$ Azospirllum @ $100 \mathrm{~g}+$ Phosphobacteria@100 g + AM fungi @ 100 g plant ${ }^{-1}$ ) registered highest ascorbic acid content $\left(7.91 \mathrm{mg} .100 \mathrm{~g}^{-1}\right)$, highest sugar acid ratio (68.61), lowest acidity percentage $(0.26 \%)$, more shelf life of fruit (10.80 days) compared to other treatments. Among the planting density, the more shelf life of fruit (10.38 days), highest sugar - acid ratio (51.45) registered in $\mathrm{P}_{1}$ (single row planting) compared to other level but no significant difference in case of ascorbic acid and acidity percentage. The interaction effect between $\mathrm{F}$ and $\mathrm{P}$ were significantly differ in respect to yield and quality parameters, the highest ascorbic acid content recorded in the treatment $\mathrm{F}_{6} \mathrm{P}_{1}\left(7.93 \mathrm{mg} .100 \mathrm{~g}^{-1}\right)$, the lowest

acidity percentage recorded in the treatment $\mathrm{F}_{6} \mathrm{P}_{1}(0.26 \%)$, the more shelf life of fruit recorded in the treatment $\mathrm{F}_{6} \mathrm{P}_{1}$ (10.81 days), the highest sugar - acid ratio recorded in the treatment $\mathrm{F}_{6} \quad \mathrm{P}_{1} \quad$ (70.05) the highest nonreducing sugar content recorded in the treatment $\mathrm{F}_{6} \mathrm{P}_{2}(5.60 \%)$ when compared to other treatment combinations (Table 3). The acidity of ripe fruit tends to decrease with the increasing rate of nitrogen application. Shelf life of fruit and total sugar increased with increase in the level of nitrogen by application of recommended dose nitrogen along with azospirillum and potassium. Adequate supply of nitrogen and potassium might have ensured optimum functioning of sucrose synthatase and suppression of hydrolytic enzymes leading to build up of greater quantity of sugars in proplastid (Nitsos and Evans,
1969).The results is line with kavino et al., (2010) and Senthilkumar et al., (2016).

\section{Acknowledgement}

The authors are highly grateful to Department of Fruit Crops, Horticulture College and Research Institute, Tamil Nadu Agricultural University, Coimbatore for providing the financial support and necessary facilities for conducting the experiments.

\section{References}

Prabhuram, R 1992. Effect of organic manures and urea on the growth and development of banana cv. Rasthali and changes in the soil ecosystem. M.Sc.(Hort.) thesis, Tamil Nadu Agril. University, Coimbatore.

Simmonds., N.W. 1982. Bananas. $2^{\text {nd }}$ edn., Longman Group Limited, London and New York

Krishnan, B. M. and K.G. Shanmugavelu. 1979. Studies on water requirements of banana cv. 'Robusta': Effect on morphological characters, crop duration, yield and quality of fruits. Mysore J. Agric. Sci., 13: 433-441.

Kavino M, Harish S, Kumar N, Saravanakumar D, Samiyappan R. Effect of chitinolytic PGPR on growth, yield and physiological attributes of banana (Musa spp.) under field conditions. Applied Soil Ecology. 2010; 45: 71-77.

Senthilkumar, M., Ganesh, S., Srinivas, K., Panneerselvam. P. and Kasinath, B. L. 2016. Combining fertigation and consortium of bio-fertilizers for enhancing growth and yield of banana cv. Robusta (AAA), Indian J. Hort., 73(1), March 2016: 36-41.

Vanilarasu, K., J. Suresh, K Soorianathasundaram, T Raguchander, $\mathrm{K}$ Devrajan and $\mathrm{K}$ Kumar Impact of 
biofertigation on growth and yield of banana $c v$. Ney poovan International Journal of Chemical Studies 2018; 6(1): 807-810.

Murugan, V. 2003. Influence of fertigation on growth and productivity of banana cv. Ney Poovan (Musa 'ab') under different planting densities. M.Sc. Thesis. Tamil Nadu Agricultural University, Coimbatore.
Lavav, E and D.W. Turner, 1983. IPI-Bulletin No.7.International Potash Institute, Bern, Switzerland.p.33

Nitsos,R.E. and Evans, H.J.1969. Effect of univalent cations on the activity of particulate starch synthatase. Pl. Physiol., 44:1260 -1266.

Tisdale and Nelson, 1966. Soil fertility and fertilizers. Macmillan co., London. Pp.81

\section{How to cite this article:}

Panjavarnam, G., S. Parthiban, A. Subbiah, P. Jeyakumar and Gopal, N.O. 2018. Studies on the Effect of Planting Density and Nutrient Management on Yield, Fruit Quality and Post Harvest Characters in Banana cv. Ney Poovan under Coconut. Int.J.Curr.Microbiol.App.Sci. 7(12): 515-520. doi: https://doi.org/10.20546/ijcmas.2018.712.064 